\title{
Financial Literacy and Sustainable Consumer Behavior
}

\author{
Ester Muñoz-Céspedes ${ }^{1}(\mathbb{D})$, Raquel Ibar-Alonso ${ }^{1, *(\mathbb{D})}$ and Sara de Lorenzo Ros ${ }^{2} \mathbb{D}$ \\ 1 Department of Applied Economics I, Universidad Rey Juan Carlos, Paseo de los Artilleros s/n, \\ 28032 Madrid, Spain; ester.munoz.cespedes@urjc.es \\ 2 Departamento de Matemática Aplicada y Estadística, Facultad de Ciencias Económicas y Empresariales, \\ Universidad San Pablo CEU, Madrid 28003, Spain; sara.lorenzoros@ceu.es \\ * Correspondence: raquel.ibar@urjc.es
}

Citation: Muñoz-Céspedes, E.; Ibar-Alonso, R.; de Lorenzo Ros, S. Financial Literacy and Sustainable Consumer Behavior. Sustainability 2021, 13, 9145. https://doi.org/ $10.3390 /$ su13169145

Academic Editors: Marc Lim, Miguel Cuerdo Mir, Luis Miguel Doncel Pedrera and Jorge Sainz-González

Received: 5 July 2021

Accepted: 12 August 2021

Published: 16 August 2021

Publisher's Note: MDPI stays neutral with regard to jurisdictional claims in published maps and institutional affiliations.

Copyright: (C) 2021 by the authors Licensee MDPI, Basel, Switzerland. This article is an open access article distributed under the terms and conditions of the Creative Commons Attribution (CC BY) license (https:/ / creativecommons.org/licenses/by/ $4.0 /)$.

\begin{abstract}
A more sustainable society and economy also implies more sustainable behavior in terms of the consumption of financial products. A possible change in this behavior can be brought about when there is a change in the demand. In other words, more sustainable consumption of financial products is directly related to financial literacy. However, the latter's definition, object, and scope are far from being agreed upon internationally. One objective of this work was to explore the different interpretations of financial literacy in academic literature. In this exploration we delved into the evolution of the term, and how, in what context, and with what other concepts the term is used in social networks. Scientometric techniques were used for the analysis and review of the literature. The NLP technique was used to analyze comments on social networks. With this technique, ten feelings that were specially selected were analyzed. Positivity, confidence, and anticipation predominated among them. We conclude that it is important to emphasize that greater attention must be given to financial literacy, from both private and public sectors, so that it can be used to drive more sustainable behavior by individual consumers. Finally, a new definition of financial literacy is proposed.
\end{abstract}

Keywords: financial literacy; financial behavior; consumer behavior; sustainable consumer behavior; social media; natural language processing; social network

\section{Introduction}

Financial education favors more sustainable behavior in terms of the consumption of financial products and leads to a more sustainable economy and society. It is evident that not all financial products present on the market today exhibit characteristics of sustainability. For this reason, a change of approach, from the supply side through the consolidation of sustainable finances and one from the demand side through more sustainable behavior of consumers, is in this sense where financial literacy plays a prominent role [1].

Both academics and economic policy makers are showing increasing interest in financial education because of its importance in making sustainable economic and financial decisions that would improve future well-being [2]. The current approach to "financial education" must include attitudes, values, and beliefs that enable informed financial decisions [3]. However, although financial education favors more sustainable behavior, it is still far-at least from an academic point of view-from being agreed upon internationally in definition, object, and scope.

When we analyze the issue of financial understanding, we find a foundational issue, one that derives from the absence of a universally accepted, conceptual definition $[4,5]$. This also makes it difficult to measure financial knowledge [6], given its qualitative nature [7], and makes it difficult to implement programs and initiatives that promote financial education [8]. Consensus on a definition would lead to finding common measurable indicators that allow assessing financial literacy and understanding its educational impact.

The main focus of this article is to show an updated and precise definition of the "financial literacy" concept. For that purpose, two strategies were used in this research. 
First, we investigated the disparate interpretations of "financial literacy" and interpreted the evolution that that phrase has undergone over time, along with its academic status at the present time. Second, we evaluated how, in what context, and with what other concepts the term is used in social networks using social listening on Twitter, one of the most popular and widespread social networks today [9].

To accomplish this, we considered the following opinions from the literature: (A1) the conversation threads that consider financial literacy are important for individuals, (A2) conversations that promote financial literacy at an early age predominate, (A3) positive feelings and trust prevail in social media posts referring to financial literacy, and (A4) the information obtained from different approaches provides a new opportunity to define financial literacy.

What is new in this article is the combination of the academic approach and a more informal approach to the concept of financial education in social networks, in order to analyze different perspectives based on the different sources used. In addition, analysis of sentiments allowed us to analyze tweets based on not only their information and arguments but also their emotional tones. This is important because financial decisions are not based solely on logic and knowledge but are influenced by emotions, personal values, and social pressure [10-12].

The rest of the article has the following structure: The second section presents a review of the existing literature on the study of financial literacy. The third section identifies the means used to extract the Twitter data and the methodology applied to the tweets. In the fourth section, we present an empirical analysis of the results. In the last section, the results are discussed, the conclusions of the study are presented, and future lines of research are proposed.

\section{Literature Review and Research Assumptions}

"Financial education" has different interpretations, and this is clearly reflected in the large number of definitions used in the literature (Appendix A). For some authors, it is a broad concept, encompassing understanding of the economy and how individual decisions are affected by economic circumstances, behavior, and financial skills. For others, it focuses strictly on basic money management [13].

John Adams, politician and second president of the United States, was one of the first people to express the importance of and need for financial education. In a letter to Thomas Jefferson, written in 1787, he stated: "All the perplexities, confusion, and distress in America arises not from deficits in the Constitution or Confederation, nor from want of honor or virtue, so much as from downright ignorance of the nature of coin, credit and circulation".

We have to look to writing almost 200 years after to find theoretical arguments relating to financial literacy again. We can therefore say that the concept of financial literacy has recently boomed in popularity. In the second half of the 20th century, the first relevant studies were carried out. They involved students from schools and universities and were related to their knowledge of efficient money management [14,15]. Both studies reflect the lack of financial literacy on the part of students. They highlight the lack of knowledge related to everyday considerations for money management-e.g., credit cards, insurance, and personal loans-and financial management in general [15]. In the last decade of the 20th century, financial literacy began to acquire importance, largely motivated by the decreasing savings rates that had been observed in American households since the beginning of the previous decade [16].

One of the first definitions presented of financial literacy was: "The ability to make informed judgments and make effective decisions about the use and management of money" [17]. Two aspects are mentioned in this definition. The first refers to financial knowledge and the second to the ability to use the financial knowledge acquired in an appropriate way to make informed decisions [18]. We consider this interpretation of the concept to be very reductionist, since it is practically limited to the nature of money. 
In the following years, the publications we found almost exclusively conflated the concepts of financial literacy and financial knowledge [19-22] in such a way that they were presented almost as synonyms. Certain studies [23] found a positive relationship between financial knowledge and making more financially responsible decisions. Although financial literacy and financial knowledge are related, empirical evidence shows that financial knowledge alone is not sufficient for making informed financial decisions [24].

Over the years, the relevance of financial literacy has grown, and studies on the subject appear to show the absence of a consistent definition of the concept. This lack of a definition has not been helpful in regard to raising the level of financial literacy [25]. The author of [25] proposed that individuals, in order to make sense of the financial information they receive and achieve the desired results, must have a base combination of skills, resources, and contextual knowledge.

Gradually, the idea that financial literacy goes a step beyond mere financial knowledge has solidified. For this reason, during the first years of this century, new concepts appeared that should be included in the definition. One of the most important additions is considering financial behavior as a fundamental variable. Evidence of this earned the 2002 Nobel Prize in Economics for psychologist Daniel Kahneman and economist Vernon L. Smith for their work on behavioral economics [26]. Their work considered that previous research on financial knowledge reveals a problem, as more financial knowledge does not necessarily translate to better financial behavior [13].

Financial literacy is a complex concept and therefore is difficult to define [27]. For that reason, the author of [27] incorporated two new dimensions other than behavior: experience and competence. It is proposed that there is a positive relationship between these variables and efficient financial management. In 2005, the Organisation for Economic Co-operation and Development (OECD) tried to clarify and integrate the subjective term "financial well-being" into the definition based on the fundamental features that appeared in the definitions listed above. This term has been the subject of multidisciplinary study and refers to one's perception of a certain standard of living and financial freedom, both in the present and in the future [28].

Other definitions which are far more instrumental relate mathematical ability in arithmetic and basic calculus to the understanding of financial terms [29-31]. These studies found positive correlations between mathematical ability and financial literacy. A certain level of mathematical ability is necessary to understand, for example, interest capitalization, and the difference between nominal and real values, and to be able to adequately diversify risk and debt. Other authors used the concept of financial arithmetic as a combination of financial literacy and financial ability [32]. In contrast, in other studies, financial literacy and numeracy were two separate competencies [33], and there is no direct correlation between numerical skills and better financial decision making [34].

In the definitions referred to above, a temporal dimension almost never appears, and it is necessary to introduce this variable [35]. An estimate of future financial well-being depends on financial behavior in the present [36]. In addition, it should be noted that one's individual perception of financial well-being can be dynamic, given the different personal and work-based situations that may arise throughout life [28,36].

In 2009, financial literacy gained visibility as a result of the economic and financial crisis unleashed in 2008, caused mainly by the over-indebtedness of a large part of the population due to the acquisition of complex, high-risk products. That is why numerous and important studies on the subject began to appear, questioning whether with higher levels of financial literacy on the part of individuals involved, the magnitude of the crisis could have been reduced and looking for indicators that would help to measure this literacy. Support for financial literacy grew as the crisis became not only a temporary moment of economic difficulties but a state of "permanent economic emergency" [37]. From the perspective of behavioral economics, two implications that this moment had for financial literacy stand out. On the one hand, it points out that individuals do not always behave rationally, as conventional economics assumed, and on the other hand, that the 
environment in which financial decisions are made is not always perfect [38]. Decisions are more informed if individuals are presented with information in a simpler way [39]. It is worth dwelling on this last point, since the origin of the economic and financial crisis of 2008 was fundamentally in a great excess of spending, and therefore indebtedness: many people acquired mortgages and complex assets they could not pay for and later alleged that they had bought these financial products without having had clear and concise information about them and without having financial knowledge.

When addressing that issue in this context of the economic and financial crisis, some authors in $[21,40,41]$ clearly determined that financial literacy was not conceptually defined at all. Therefore, on occasion, the definition must be deduced by context or based on how an author has measured financial competence. Proof of this is that, in their research, different definitions that had been formulated previously by various authors were collected. In addition, this diversity in defining financial literacy also causes a disparity in the methods used to measure it, which makes it difficult to find a homogeneous model that allows financial literacy indicators to be measured in a predictable and repeatable way.

In one international study, financial literacy was considered as a combination of knowledge, attitudes, and behaviors. In their contribution to the attempt to clarify the concept, they defined it as "a combination of awareness, knowledge, skill, attitude and behavior necessary to make sound financial decisions and, ultimately, achieve individual financial well-being" ([42], p. 50). Numerous subsequent investigations analyzed this contribution and highlighted that what is remarkable about this interpretation is that financial literacy is not an objective itself, but a means to achieve and maintain financial well-being [43]. Other research has emphasized the inclusion of financial attitudes, such as the desire to save in the long term, and financial behaviors, such as preparing a family budget [44].

Financial literacy to date has been fundamentally based, as previously stated, on studies that focused on the more objective aspects of the concept, that is, on real financial knowledge, normally measured through academic tests and not perceived [8]. Allgood and Walstad [5] incorporated the subjective dimension by assessing the importance of individuals' self-perceptions - that is, what people think they know about financial matters. The combined study of real and perceived financial knowledge obtained more conclusive results on how financial knowledge is related to behavior [45]. This new dimension was also relevant to Xiao and Cheng, who added perceived financial capacity and trust to the binomial of financial literacy and behavior [46]. Other prominent authors have researched how our perceptions and options that are presented to us affect our decision making. For example, in matters such as retirement and savings plans, these "pushes" and the "architecture of decisions" are presented as more effective alternatives to financial literacy and are far less expensive to implement [47].

Currently, most studies are based on the OECD definition (2014): "Knowledge and understanding of financial concepts and risks, and the skills, motivation and confidence to apply such knowledge and understanding in order to make effective decisions across a range of financial contexts, to improve the financial well-being of individuals and society, and to enable participation in economic life" ([48], p. 11). Following this interpretation, some studies have described financial literacy as a dynamic combination of knowledge and skills, behaviors, and attitudes [49-51] and incorporate other factors such as sociodemographic characteristics and financial training.

In recent years, given the multidimensional nature of the subject, many authors presented a multidisciplinary vision, showing that financial literacy affects a wide range of financial behaviors [52]. A direct relationship was empirically demonstrated between better financial literacy and decision making that led to greater accumulation of wealth in households [53], among other things. For example, more adequate retirement planning [54], stock market participation [55], increased savings rates [56], more efficient mortgage management [57], superior transitioning to adulthood by young people [58], financial inclusion [22,59], and an overall beneficial effect on financial well-being [28]. 
$1787-1990$

2000-Crisis 2008

Crisis 2008-2013
In two studies [60,61], the research methodology managed to map scientific knowledge based on bibliometric tools to learn the development and evolution of scientific opinions followed by authors, faculties, countries, and scientific journals; and the choices of topics, such as terms and trends in relation to the study of financial literacy.

In the field of Marketing, some publications $[62,63]$ incorporated some new dimensions into the concept of sustainability. Some prominent theoretical perspectives, such as responsible consumption, anticonsumption, and mindful consumption, are crucial to analyzing the concept of sustainability among consumers.

In 2020, the OECD simplified and summarized the concept of financial literacy compared to those expressed in 2005 and 2014. It was defined it as a "combination of awareness, knowledge, skills, attitudes and behaviors necessary to make good financial decisions and, ultimately, to achieve individual financial well-being". The evolution of the concept and its significance are shown in the diagram (Figure 1).

\section{Money management,}

First studies with high school students and university students.

Financial education $=$ Financial knowledge .

Financial education =Mathematical ability .

Boom in behavioral economics,

Financial education $=$ Knowledge + Financial behavior .

- Studies reflect that the term is ill-defined.

- Difficulties in finding indicators to measure financial education.

- Incorporation of new variables in the definition:

-Experience and competence;

-Financial wellness;

-Conscience and attitude;

-Subjective dimension.

Financial education is studied as a disciplinary competence.

Figure 1. Financial literacy evolution diagram.

\section{Methods and Data Collection}

\subsection{Methods}

In this research, the structure of the relationships among content concerning financial literacy generated in social networks has been studied using the natural language processing (NLP) technique of social network analysis. An analysis was performed of the tweets containing the words "financial literacy", "financial knowledge", and "financial education" on the social network Twitter to discover the main terms and sentiments linked to them. The methodology followed in this work is as follows (Figure 2): 
Figure 2. A schematic diagram of the methodology used.

In the first phase, Twitter was chosen for this study because it is an open platform [64], which means that this social network has become a precious data laboratory that allows the analysis of dissemination mechanisms and information content [65] and also provides a series of APIs (application programming interfaces) with which such data can be obtained. The data extraction, processing, and analysis processes were carried out with $\mathrm{R}$ software, which allows working with large volumes of data. $\mathrm{R}$ was used because it is a statistical programming language that consists of thousands of integrated packages and various functions [66]. These packages allowed us to handle a high volume of data, use advanced statistical analysis techniques, and visualize the results. R Studio version 1.4.1106, a very useful $\mathrm{R}$ editor, was used, and RMarkdown documents (.Rmd) that provide a writing framework for data science by combining the code, the results, and the comments were used.

The data extraction was carried out by developing our own script in the R programming language, for which the Rtweet library was used, which allows communication with the API. For this research, the entire API registration process was carried out to gain permission to download public information present on the platform. Once the API was created, a series of passwords and sets of code were obtained that served to put RStudio in contact with the API and make it able to perform the download.

After the extraction of tweets, we began the cleaning of the text, within the scope of text mining, for which libraries such as tidyverse, tidytext, stringi, and topicmodels were used. Everything that did not provide information was eliminated from the text, such as punctuation marks, numbers, blank spaces, special characters, and the so-called stopwords that add little value to the analysis due to their semantic content. By eliminating the latter from the text, we ensured that when performing the analysis they did not appear among the most frequent words found; in addition, it was possible to include a term that was considered necessary to eliminate. To facilitate our later analysis, a new variable was created with the prepared and cleaned text.

Once the text extraction and debugging process are finished, natural language processing (NLP) was used to analyze the frequencies of words [67]. For this purpose, a process of tokenization and elimination of stopwords was applied that included converting all text to lowercase. We proceeded to create our corpus, the nov_corpus object using the VectorSource and Corpus functions. Code created from various R libraries was used, such as Wordcloud, which is commonly used in data science. The word occurrence count also allows word clouds to be gathered, which is an increasingly widespread method, as it is very efficient when it comes to summarizing huge amounts of data [68,69]. To analyze the terms together to strengthen the understanding and interpretation of the concept, word clouds were created for a visual representation of the text, and a tokenization process was carried out to divide the text into n-grams $(n=1,2,3)$.

This was followed by lexical-based sentiment analysis, which is a subfield of natural language processing (NPL) used to detect and extract opinions from a text [70]. The subjective content of the text-the emotions and feelings involved-extracted from the social network Twitter was identified and classified as positive or negative [71]. For this purpose, lexicons or dictionaries of words and expressions were established that could be used later by a mathematical algorithm to specify the semantic orientation of the text [72]. To categorize the words of each tweet, the get_nrc_sentiment function was used, which returned a data frame which gave us a score for each row of the vector according to the NRC emotion lexicon [73]. It has a wide range of applications and is used in a multitude 
of contexts, such as sentiment analysis, product marketing, consumer behavior, and even political campaign analysis. This lexicon-having ten categories in total-contains a list of words and their associations. There are eight basic emotions-anger, anticipation, disgust, fear, joy, sadness, surprise, and trust-with which the words of each tweet are classified, and a positive or negative score is given that represents positive or negative feelings [74]. From this analysis, ten variables were created that measured the frequencies of words that relate to feelings or emotions.

Finally, a sentiment clustering process was applied. The sentiment analysis performed in this study used 10 new variables for each tweet -8 different emotions and 2 feelings - which allowed us to distinguish between positive and negative feelings and emotions behind each tweet.

In the context of text mining, sentiment analysis is used to detect the subjectivity of some text in terms of opinions, emotions, or feelings [75]. The sentiment classification of the tweets has been evaluated as in other works in which classification algorithms for emotions, opinions, and attitudes were implemented [76].

Some publications have been found in the recent literature where the tweets were grouped based on unsupervised classification techniques [77]. Rehioui and Idrissi [78] used $\mathrm{k}$-means with hierarchical clustering to group tweets according to sentiments classified as positive, negative, or neutral. This clustering algorithm has been used in several publications, such as Burscher et al. [79], who classified content from newspaper articles based on the feelings found therein in relation to the framing of the news. Harakawa et al. [80] presented a comprehensive review of such clustering methods.

Regarding the different clustering algorithms that exist to classify populations, Garre et al. [81] selected an unsupervised algorithm which oversees looking for patterns in unlabeled data. Fisher [82] used hierarchical clustering to discover clusters of tweets that would allow them to see relationships between variables of sentiment and variables of emotion. Both variables were estimated prior to the sentiment analysis. In this case, the tweets were grouped into clusters with high degrees of internal homogeneity and external heterogeneity, as was explained by Joseph F. Hair in his publication [83]. The technique used is called the hierarchical cluster with the Ward clustering method. This original method allows one to minimize dispersion within clusters, and the stopping rule is applied from the analysis of the clustering history and elbow method.

In the last phase, we carried out analysis of variance (ANOVA) testing. This methodology allowed us to test whether the mean values of the feelings variables and emotions variables were significantly different in the clusters (F of Fisher Snedecor's) [84]. For this purpose, fixed-effects ANOVA was used. Independent variables were the variables of feelings and the variables of emotions estimated with the sentiment analysis.

\subsection{Data Collection}

To carry out this research, a sample of tweets which had been published from 14 March to 30 May 2021 was extracted from the social network Twitter. Within the twitteR package, there are many functions, among which is the searchTwitter() function, which allowed us to download a sample of tweets that contained any of these keyword chains: "financial literacy", "financial knowledge", and "financial education". In addition, filters were applied to capture date and ensure the downloads were in English.

Carrying out this process consisted of downloading weekly tweets and then merging the weekly databases into one, which contained 53,819 collected tweets. This information was processed and analyzed with R scripts. For this, natural language processing (NLP) libraries were used for word cloud elaboration, sentiment analysis, and cluster analysis. The resulting database consisted of 90 variables and 53,819 rows. Most of our analysis was carried out with the text variable, which includes the content of the comments. The details of the weekly pools of tweets are shown in Table 1. 
Table 1. Download details.

\begin{tabular}{ccc}
\hline $\begin{array}{c}\text { Date } \\
\text { 14 March 2021 from 30 May 2021 }\end{array}$ & $\begin{array}{c}\text { Weekly Download } \\
\text { of Tweets }\end{array}$ & $\begin{array}{c}\text { Accumulated } \\
\text { Tweets }\end{array}$ \\
\hline 14 March-21 March & 3916 & 3916 \\
22 March-28 March & 4485 & 8401 \\
29 March-4 April & 5346 & 13,747 \\
5 April-11 April & 6410 & 20,157 \\
12 April-18 April & 6216 & 26,373 \\
19 April-25 April & 6166 & 32,539 \\
26 April-2 May & 5994 & 38,533 \\
3 May-9 May & 4617 & 43,150 \\
10 May-16 May & 3481 & 46,631 \\
17 May-23 May & 3458 & 50,089 \\
24 May-30 May & 3730 & 53,819 \\
\hline
\end{tabular}

\section{Empirical Analysis and Results}

The responses to the COVID-19 pandemic caused substantial damage to the global economy, and as mentioned above, interest in financial literacy takes on greater relevance in times of global crisis.

The period we focused on coincides with mass vaccinations, worldwide, which is considered a key factor for economic recovery, as it drives up all economic forecasts.

In addition, the collection of tweets covered the month of April, which is considered in some countries to be Financial Literacy Month, in which initiatives are developed to promote the acquisition of both skills and competencies that help people to make suitable decisions.

\subsection{NLP Analysis}

Initially, frequency analysis was carried out, in which the relationships of the downloaded tweets with the chains of keywords consulted in the extraction process were observed (Figure 3).

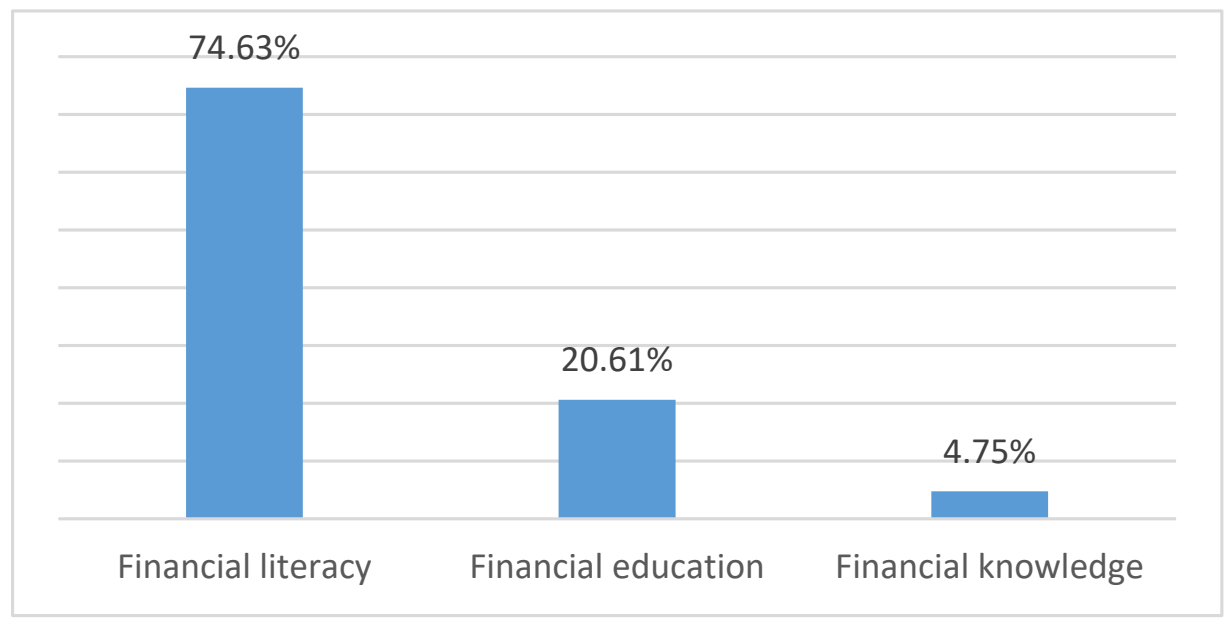

Figure 3. Word string frequency analysis.

Although, as mentioned above, these three phrases are frequently used interchangeably when referring to financial literacy, on the social network Twitter, the term that is most used is "financial literacy". This term is used considerably more frequently than "financial education" and "financial knowledge", although the latter appears in some of the academic definitions.

In order to identify the most notable topics and concepts related to the three keyword chains used in the downloaded tweets, an analysis of the 100 most common words used 
in the word cloud of the text of the comments was performed (Figure 4). The major keywords that appeared literally in the search were: "financial", appearing 60,796 times, and "literacy", appearing on 38,199 occasions. "Education" appeared 13,139 times. The term that came in fourth was "money", following far behind. Among the first 30 positions, $30 \%$ corresponded to verbs "can", "help", "learn", "need", "make", "teach", "get", "like", and "know". Other terms with great presence are those related to school and young people: "school", "students", and "kids". These terms are related to the importance of receiving financial literacy from an early age.

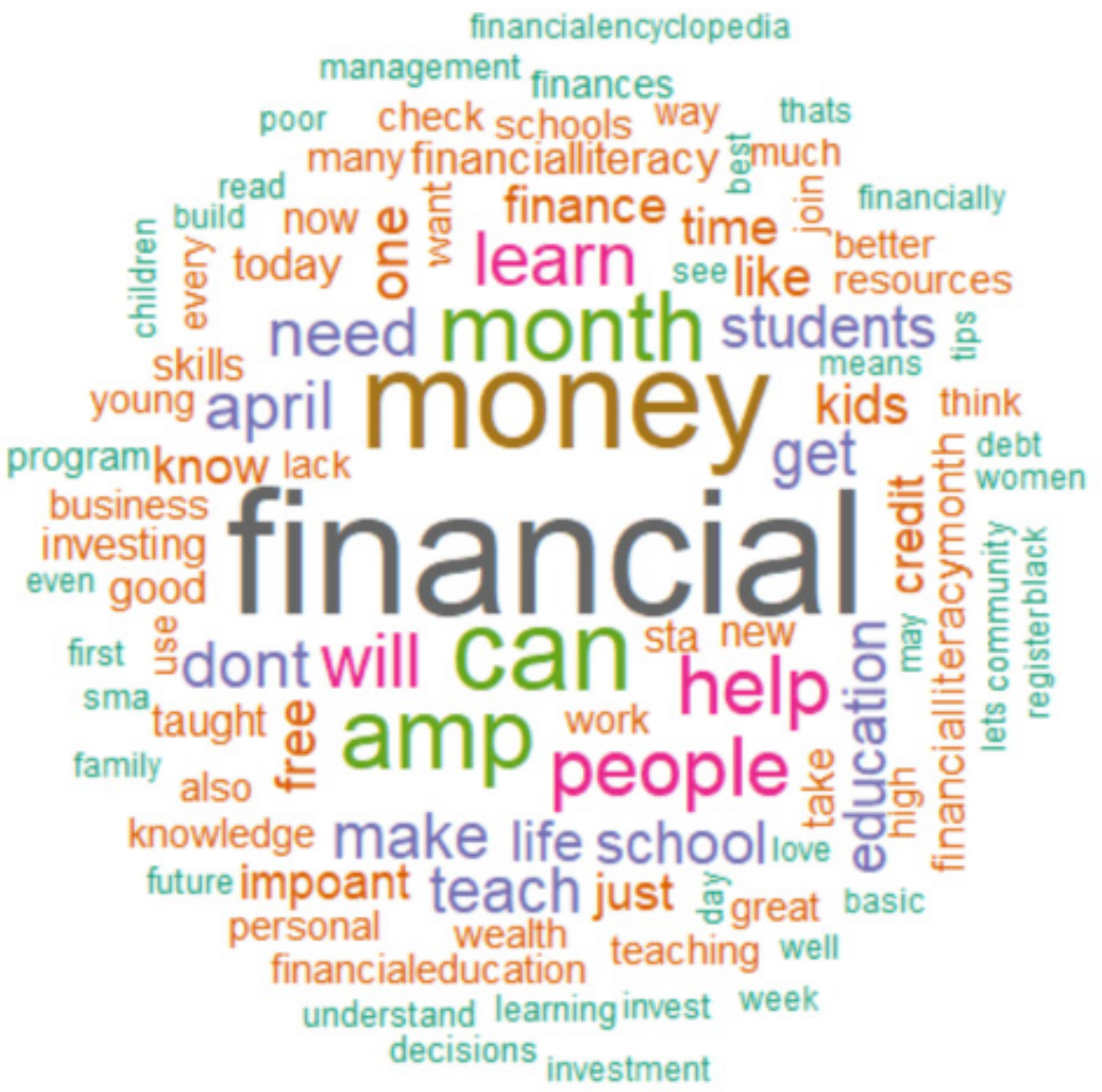

Figure 4. Diagram of a Wordcloud analyzed by NLP.

Although financial literacy is fundamental throughout the life of any person, the reality is that it is an area of knowledge that, in general, is not studied in schools or universities $[35,85]$, unless it is in subjects that are related to the theme.

In addition, among the 15 most frequent terms were the words "month" and "April". This is because April is considered the Month of Financial Literacy, in which effort is made to create awareness and promote financial culture. To this end, the Jump\$tart Coalition and its partners organize events and initiatives throughout the month.

Next, the n-grams ( $n=2,3,4)$ of the tweets were analyzed. It was observed that the most important contribution was from the bigrams, which reinforces our interpretation of the previous results. Without considering the key bigrams used in the collection of tweets, "can help" appeared on 1274 occasions and "April month" on 1257, followed by others such as "high school" and "financial decisions" (Figure 5). 


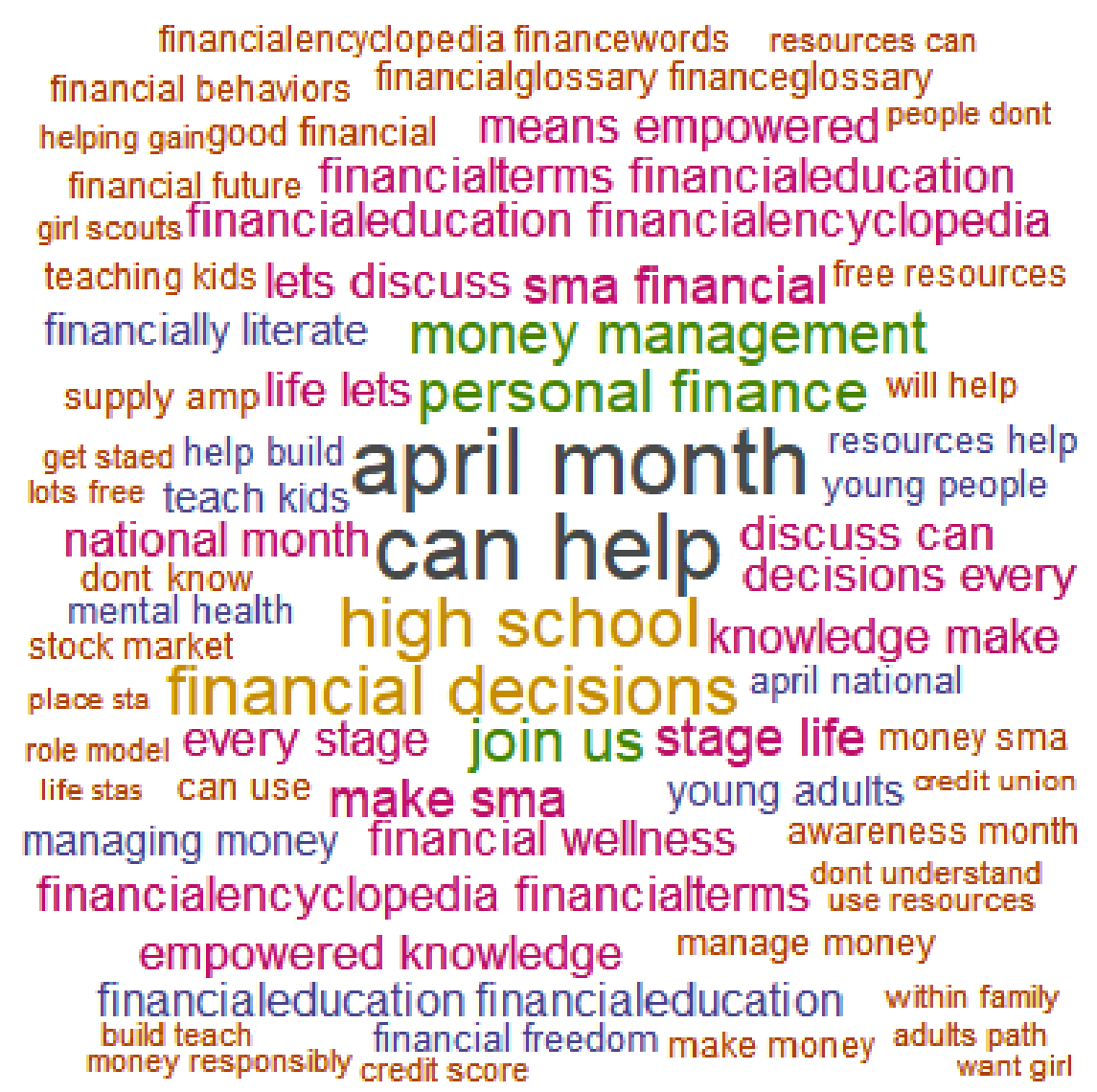

Figure 5. Diagram of a Wordcloud analyzed by bigrams.

Financial literacy has great benefits and can help us make informed decisions, such as saving for retirement [86] and negotiating mortgage terms [87]; therefore, active Twitter users are aware of the usefulness that financial education offers in our lives. A wellinformed citizen is in a better position in regard to financial entities. Examples of benefits include reducing one's risk of being exploited by some financial products and diversifying one's investment portfolio. Being well informed also enables citizens to be alert to hypothetical fraudulent behavior in the digital age and to know where to turn for help and financial advice.

\subsection{Analysis of Sentiments}

A tweet on this subject may be related to the emotional situation of the person who wrote it; therefore, it is interesting to analyze the feeling that is extracted from the tweets. We analyzed whether the conversations containing the keyword strings "financial literacy", "financial knowledge", and "financial education" occurred in a positive or negative context in the Twitter community.

The emotions with the greatest presence in the text were identified (Figure 6). We detected that the predominant sentiments were positive. As Ameliawati says, experience, attitudes, and financial knowledge have positive influences on financial management [88]. Financial literacy is the fundamental engine for the resilience of the individual economy and contributes to the acquisition of healthy financial behaviors that favor the financial well-being of society. Financial literacy not only requires knowledge and understanding of financial products; it also requires developing positive attitudes and the ability to identify and manage human tendencies that, at times, undermine the achievement of our financial plans and objectives. Behavioral economics, which takes psychology into account, recognizes that although we are rational beings, we frequently manifest irrational 
behaviors, since our financial decisions are not exclusively guided by logic, reasoning, and analysis, but by emotions, heuristics, and prejudices as well [89].

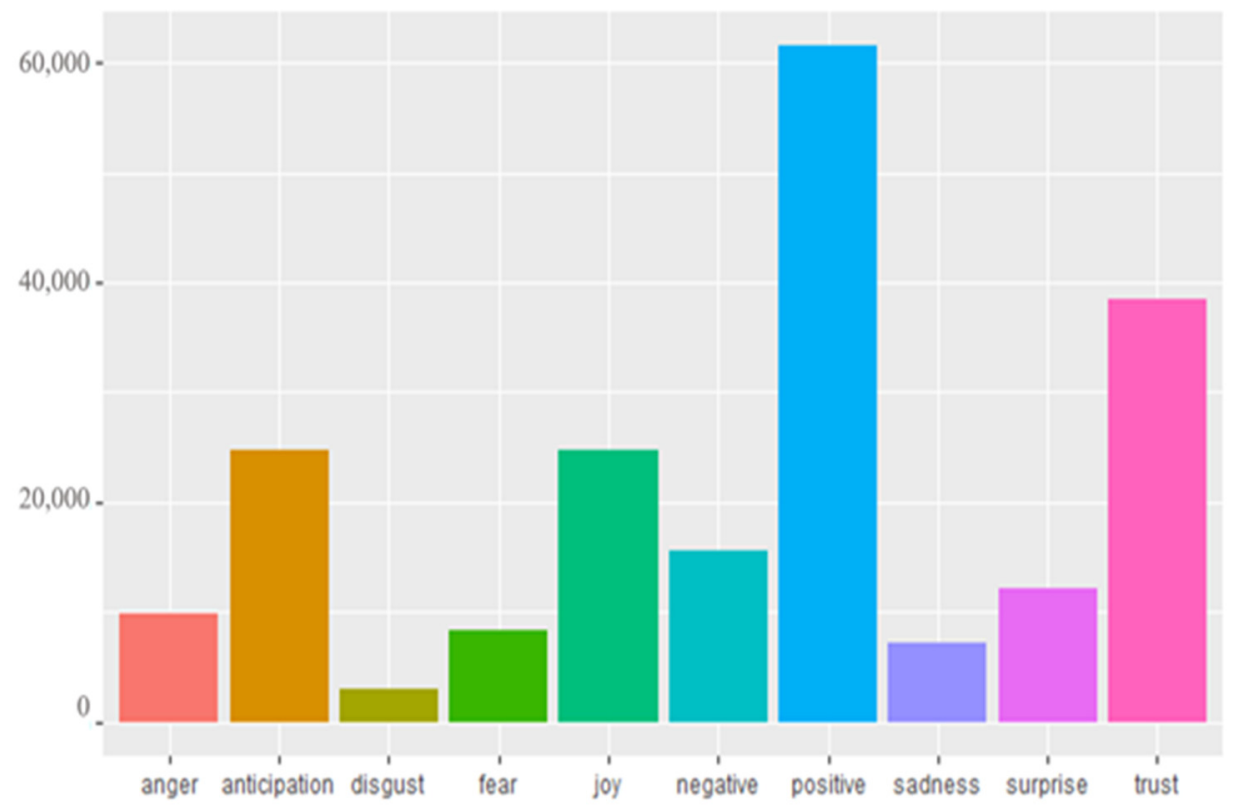

Figure 6. Graph showing analysis of sentiments.

There are also numerous tweets that reflect confidence. It is realistic to conclude that more knowledge and greater confidence would lead to favorable behaviors, such as saving and investing [90]. Along these lines, the next emotion in absolute frequency was anticipation. Planning in advance shows that people are future-oriented and willing to improve their financial situations. Financial planning for retirement is a complicated task that requires thinking about the future and saving based on anticipating the economic needs that would be experienced at that stage [86,91]. This topic is particularly relevant because the reforms that are being carried out in almost all countries are in line with transferring greater responsibility to the individual in terms of managing pensions and saving for long-term retirement. In addition, some sociodemographic changes are making financial decisions more complex, among which are the increase in the level of indebtedness in recent decades, the increase in life expectancy, and the growing instability in the world of work [92]. In this financial context, people today have a greater responsibility for their financial well-being than in times past.

Negative emotions and feelings have little representation in the collected tweets. Anger, sadness, and fear appear rarely. Lack of knowledge can generate fear and inaction. We feel intimidated by what we do not understand; we feel insecure. Therefore, it is vital to train people to understand what risks exist, weigh risks and profitability, and make informed decisions. Overall, "Financial literacy leads to fewer financial worries and a higher level of financial well-being" [93].

\subsection{Cluster Analysis}

The tweets collected are of very diverse origins and were written by a very heterogeneous population. This section seeks to identify the groups of homogeneous comments in terms of the multidimensional sentiments that they transmit in the Twitter community.

A clustering process was carried out based on the scores assigned to each of the two feelings and eight emotions identified in the sentiment analysis. The stopping rule was used to select the optimal number of clusters with the elbow method. This method was applied with the cluster coefficient defined as the difference between the grouping coefficients of successive stages calculated in the cluster history (Table 2). Figure 6 represents the grouping coefficients against the number of clusters. The point where there is a sharp 
change in the trend of the graph is the optimal number of clusters. In Figure 7, there is a sudden change in the trend at three groups; therefore, the optimal number of groups was three. In this figure, only the last 20 stages are represented because we only wanted to find a relatively small number of clusters that can be evaluated. Of the 53,819 tweets collected and evaluated: 20,186 belonged to group 1, the majority; 13,622 to group 2; and 20,011 to group 3.

Table 2. Conglomeration history.

\begin{tabular}{|c|c|c|c|c|c|}
\hline \multirow{2}{*}{ Stage } & \multicolumn{2}{|c|}{ Combined Cluster } & \multirow{2}{*}{ Coefficients } & \multirow{2}{*}{$\begin{array}{c}\text { Cluster } \\
\text { Coefficients }\end{array}$} & \multirow{2}{*}{$\begin{array}{c}\text { Number of } \\
\text { Clusters }\end{array}$} \\
\hline & Cluster 1 & Cluster 2 & & & \\
\hline 1 & 53,811 & 53,819 & 0.000 & 0 & 1 \\
\hline 2 & 53,798 & 53,818 & 0.000 & 0.000 & 2 \\
\hline 3 & 34,849 & 53,817 & 0.000 & 0.000 & 3 \\
\hline 4 & 51,557 & 53,816 & 0.000 & 0.000 & 4 \\
\hline 5 & 34,844 & 53,815 & 0.000 & 0.000 & 5 \\
\hline \multicolumn{6}{|c|}{ (53,793 skipped rows) } \\
\hline 53,799 & 12 & 26 & $92,503.829$ & 1820.381 & 20 \\
\hline 53,800 & 37 & 87 & $94,407.402$ & 1903.573 & 19 \\
\hline 53,801 & 4 & 6 & $96,455.778$ & 2048.375 & 18 \\
\hline 53,802 & 14 & 25 & $98,588.518$ & 2132.741 & 17 \\
\hline 53,803 & 9 & 12 & $101,315.067$ & 2726.549 & 16 \\
\hline 53,804 & 1 & 2 & $104,068.079$ & 2753.012 & 15 \\
\hline 53,805 & 8 & 14 & $106,907.505$ & 2839.426 & 14 \\
\hline 53,806 & 27 & 359 & $110,061.445$ & 3153.940 & 13 \\
\hline 53,807 & 5 & 1554 & $114,020.362$ & 3958.917 & 12 \\
\hline 53,808 & 23 & 24 & $118,372.435$ & 4352.074 & 11 \\
\hline 53,809 & 1 & 15 & $123,234.197$ & 4861.761 & 10 \\
\hline 53,810 & 8 & 56 & $129,056.246$ & 5822.049 & 9 \\
\hline 53,811 & 8 & 20 & $135,559.716$ & 6503.470 & 8 \\
\hline 53,812 & 1 & 4 & $143,715.133$ & 8155.417 & 7 \\
\hline 53,813 & 9 & 37 & $152,199.658$ & 8484.526 & 6 \\
\hline 53,814 & 9 & 23 & $161,365.722$ & 9166.063 & 5 \\
\hline 53,815 & 8 & 27 & $179,420.814$ & $18,055.093$ & 4 \\
\hline 53,816 & 5 & 8 & $200,134.650$ & $20,713.835$ & 3 \\
\hline 53,817 & 1 & 9 & $239,150.698$ & $39,016.049$ & 2 \\
\hline 53,818 & 1 & 5 & $373,583.953$ & $134,433.255$ & 1 \\
\hline
\end{tabular}

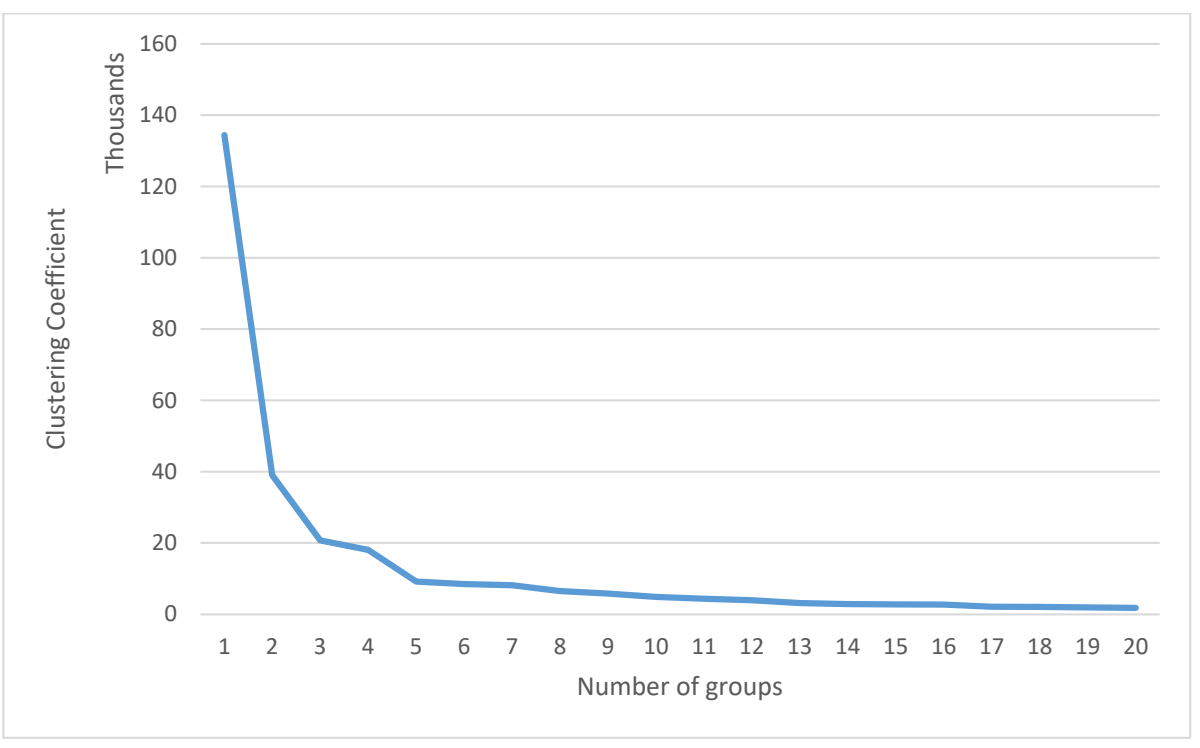

Figure 7. Elbow method. 
The analysis of variance (ANOVA) revealed the equality of the means of the three groups for each variable of some emotion or feeling. It showed that there was a significant difference in the three groups; therefore, sentiments and emotions allowed the tweets to be classified into three different groups (Table 3).

Table 3. ANOVA: Table of cluster analysis.

\begin{tabular}{cccccccccc}
\hline & \multicolumn{3}{c}{ ANOVA } & \multicolumn{2}{c}{ Cluster 1 } & \multicolumn{2}{c}{ Cluster 2 } & \multicolumn{2}{c}{ Cluster 3 } \\
\cline { 2 - 10 } & gl & $\mathbf{F}$ & $p$-Valor & Average & Sd & Average & Sd & Average & Sd \\
\hline Anger & 2 & 4223.736 & 0 & 0.1 & 0.329 & 0.63 & 0.715 & 0.29 & 0.517 \\
Anticipation & 2 & $16,416.391$ & 0 & 0.16 & 0.407 & 1.66 & 1.081 & 0.76 & 0.738 \\
Disgust & 2 & 435.238 & 0 & 0.06 & 0.249 & 0.17 & 0.452 & 0.1 & 0.314 \\
Fear & 2 & 1681.358 & 0 & 0.15 & 0.381 & 0.48 & 0.737 & 0.23 & 0.473 \\
Joy & 2 & $36,594.183$ & 0 & 0.1 & 0.074 & 1.93 & 1.113 & 0.75 & 0.507 \\
Sadness & 2 & 833.411 & 0 & 0.15 & 0.388 & 0.38 & 0.706 & 0.22 & 0.470 \\
Surprise & 2 & $11,463.502$ & 0 & 0.03 & 0.17 & 0.96 & 0.884 & 0.37 & 0.515 \\
Trust & 2 & $22,458.211$ & 0 & 0.32 & 0.563 & 2.42 & 1.236 & 1.24 & 0.887 \\
Negative & 2 & 792.458 & 0 & 0.37 & 0.679 & 0.72 & 1.098 & 0.46 & 0.704 \\
Positive & 2 & $55,068.906$ & 0 & 0.44 & 0.524 & 3.91 & 1.473 & 1.98 & 0.800 \\
\hline
\end{tabular}

In all groups, the predominant feelings were positive. However, it is noticed that in cluster 1, negative sentiment was in the second position, whereas we must go to positions 6 and 7 to find it in clusters 2 and 3 . Therefore, it is possible to conclude that it is this group that shows a more pessimistic mood in conversations that deal with financial literacy. Group 2 contained the most emotional tweets, which is why it revealed higher average levels of emotion. This characteristic indicates that Twitter users who belonged to this group were the most expressive in terms of their emotions, since they present the highest average amounts of feeling in all the categories. In addition, "joy" stands out in the third group. We can affirm that the tweets in cluster 3 were more optimistic. Cluster 3 shared traits with the other clusters and had levels of emotion between the other two clusters.

The influence of the "trust" sentiment in the three groups indicates that the analyzed tweets contained connotations of certainty and security about the subject studied. On the other hand, "disgust" was not very prominent in the tweets referring to financial literacy, which conveys that it does not cause negative feelings.

When analyzing the frequency of words in the clusters, it was observed that the most used term in groups 1 and 3 was "financial", with 3234 and 4355 appearances, respectively. In cluster 2, the most frequent was "money", appearing 5328 times (Figure 8). It should be remembered that it was precisely this group that was the most expressive in terms of showing feelings. Finance is related to happiness in the Twitter community. The three groups agree in that they have among their top positions verbs such as "can", "help", and "know"; and terms related to education, such as "school", "student", "education", and "kids". When analyzing the 10 most-used words of each group, it was observed that five terms took top positions in all clusters, as shown in Figure 9. The word cloud detected that "financial", "money", "can", "help", and "people" were the most common, which allowed us to know which topics are relevant to Twitter and to build a definition of financial literacy, which is one of the purposes pursued in this study. 


\begin{tabular}{|c|c|c|}
\hline Cluster 1 & Cluster 2 & Cluster 3 \\
\hline 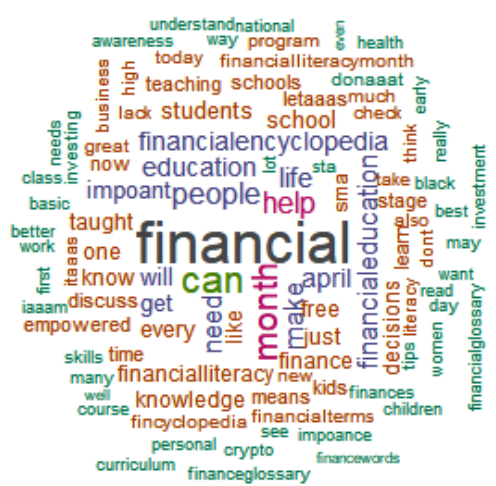 & 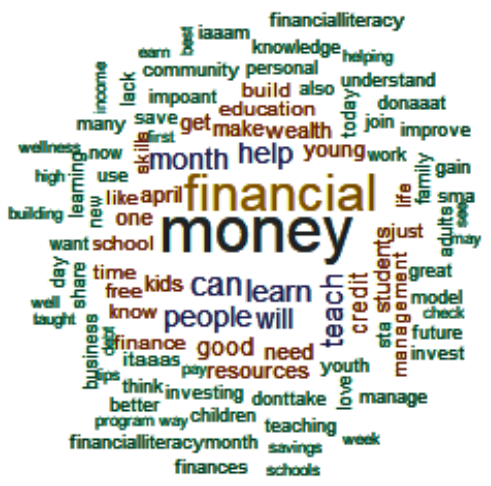 & 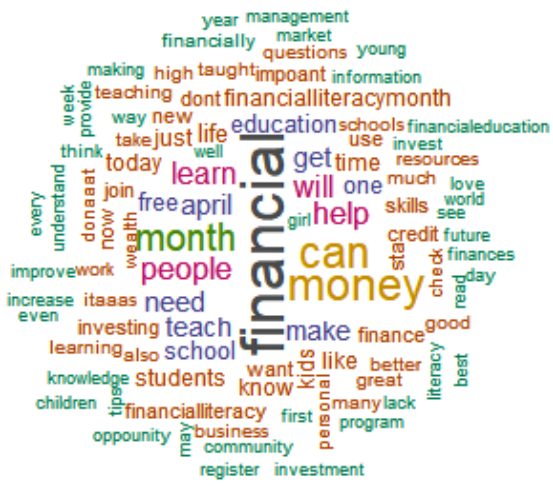 \\
\hline
\end{tabular}

Figure 8. Wordclouds with relative frequencies of words divided by clusters.

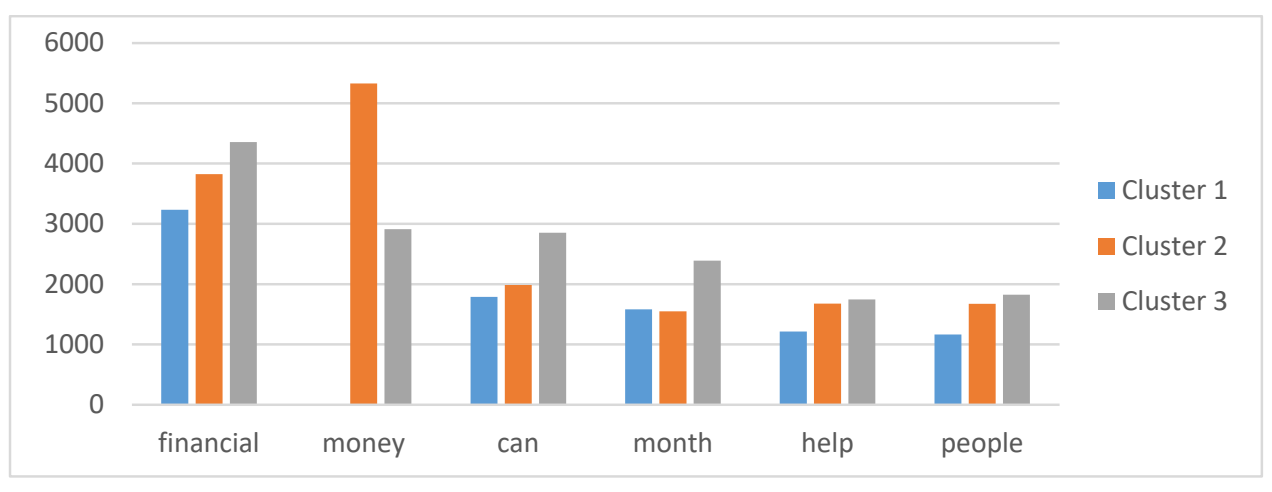

Figure 9. Graph of word string frequency analysis, divided by clusters.

Continuing with the analysis, we detected in the study of bigrams that "can help" was used very frequently in the tweets of all three clusters and "can" appeared together with other terms that give it greater meaning such as "can help", "can build", and "can use" (Figure 10). In the second group, "money management" stood out as the most repetitive phrase, which relates to the first academic definitions of the term financial literacy. To this day, money remains an essential tool for humanity. The financial historian William Goetzmann [94] maintains in his work "Money changes everything" that financial technologies and institutions favor the development of culture and warn us of the challenges we face in the future, having an increasingly aging population. Along these lines, "young adults" and "high school" also stand out. It is essential to design the necessary mechanisms that ensure young people have access to financial literacy and thus do not become a burden for governments [95]. To achieve well-being and economic independence, it is necessary to invest in financial literacy, mainly in young people, since according to the OECD 2010, younger generations are not only likely to face ever-increasing complexity in financial products, services, and markets, but they are more likely to have to take more financial risks in adulthood than their parents. A person who has received training in personal finance does not think that all his economic decisions are the products of external circumstances but feels empowered to guide his financial future based on his own goals.

Expressions referring to the month of April appeared in the bigrams, most frequently in the bigram of cluster 3 . This indicates that on social networks it is a recurring theme due to the perception about the need for institutions, both public and private, to invest in and contribute to greater dissemination of financial literacy. Financial decision-making processes have puzzled researchers for decades in various fields of research, such as psychology, business management, and economics. When considering finance as a decision-making process in which emotions play a prominent role, we cannot separate these concepts from behavioral approaches. Until now, financial literacy programs were limited to transmitting 
information about financial products and services based on the same false premise of Homo economicus, but as it has been shown, steps must be taken to improve financial decision making throughout people's lives. Positive behaviors related to saving and managing money should be encouraged. To achieve this goal, we must not forget the psychological and emotional aspects of these behaviors. Along these lines, well-founded programs on emotional intelligence could provide useful tools for making the right decisions. Despite not being a reality yet, it is a good place to start.

\begin{tabular}{|c|c|c|}
\hline Cluster 1 & Cluster 2 & Cluster 3 \\
\hline 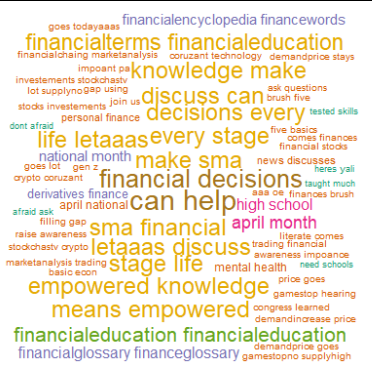 & 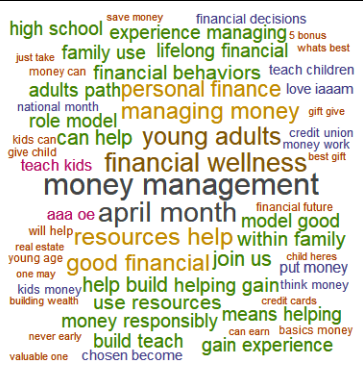 & 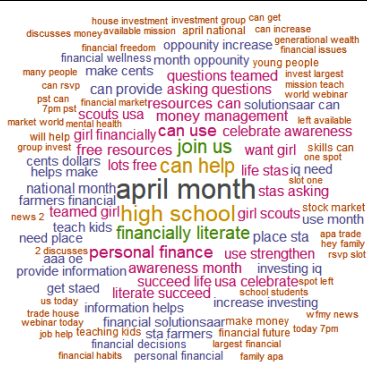 \\
\hline
\end{tabular}

Figure 10. Wordclouds with relative frequencies of words divided by clusters.

\section{Discussion and Conclusions}

In this study, a novel method was developed to investigate the concept of financial literacy. The combination of the academic approach and a more informal one with regard to social networks allowed us to observe different perspectives based on the different sources.

Previous studies revealed the lack of a consistent definition of financial literacy. Definitions began by being very reductionist - the term was almost exclusively related to money management or financial knowledge. More recent definitions consider financial behavior and subjective aspects such as emotions, which require multidisciplinary study.

The findings of the research support A1, since financial literacy can help people make informed decisions that contribute to their own financial well-being and to that of society in general. This result agrees with the conclusions obtained in [96]. Namely, people believe that financial education has benefits and leads to a more financially resilient future. It has a positive impact on financial decision making that has consequences for individuals, communities, countries, and society, making it easier to face the economic challenges that may arise.

A2 was also confirmed by frequent conversations in which terms related to education and students appeared. Twitter users are committed to financial education in school, since it can be valued as an investment in the future, not only for young people but for society. This opinion is corroborated by evidence that financial education at school may result in more solid financial behavior in the future [97].

In relation to A3, it was shown that the feelings generated by the conversation were mostly positive and that the emotions that were aroused had positive connotations. Emotions influence our decisions and therefore can affect financial decision making. Some studies, such as [98], support how this knowledge can be used to improve the decisionmaking process.

Regarding A4, the information obtained from different approaches favors the creation of an updated definition of financial literacy.

The aim of this study was to obtain a definition of financial literacy that considers terms or expressions that are used in a more informal environment and that allows contributions to the understanding of the concept, since from its origin it has had different interpretations and nuances. Furthermore, heterogeneous groups have been found to have varied feelings of varied intensities about financial literacy.

Based on our research, carried out by reviewing the academic literature and complemented with natural language processing and statistical analysis based on the feelings 
and emotions of the sample of 53,819 tweets extracted from Twitter, a new definition was thought up. It is based on of the most common terms that are expressed when dealing with the issue and the final definition offered by the OECD in 2020.

That definition is: "the combination of awareness, knowledge, skills, attitudes, and behaviors that help people make informed financial decisions that ensure their present and future financial well-being".

The limitations found in this research are those related to the extraction of tweets, since they were collected at a specific time of year and that the analysis was based exclusively on tweets in English, though they were deliberately obtained in that language due to their relevance in the financial environment.

As a future line of research, we propose carrying out the research in other languages, such as Spanish, to help us better understand the term financial literacy and contribute to its conceptual definition, which should also allow finding common measurable indicators with which to addressing financial literacy from a global perspective. In this way, the development of financial literacy programs and initiatives will be aided, and we will enhance knowledge and skills in this field effectively.

Author Contributions: Conceptualization, E.M.-C.; R.I.-A. and S.d.L.R.; Methodology, E.M.-C. and R.I.-A.; Data curation, E.M.-C. and S.d.L.R.; Validation, E.M.-C.; R.I.-A. and S.d.L.R.; Formal analysis, R.I.-A.; Investigation, E.M.-C.; Project administration, R.I.-A.; Software, E.M.-C. and R.I.-A.; Supervision, R.I.-A. and S.d.L.R.; Visualization, E.M.-C. and S.d.L.R.; Writing-original draft, E.M.-C. and R.I.-A.; Writing—review \& editing, S.d.L.R. All authors have read and agreed to the published version of the manuscript.

Funding: This research received no external funding.

Institutional Review Board Statement: Not applicable.

Informed Consent Statement: Not applicable.

Data Availability Statement: Not applicable.

Conflicts of Interest: The authors declare no conflict of interest.

\section{Appendix A}

\begin{tabular}{|c|c|}
\hline $\begin{array}{c}\text { John Adams } \\
(1787)\end{array}$ & $\begin{array}{l}\text { All the perplexities, confusion and distress in America arise not from defects } \\
\text { in their Constitution or Confederation, nor from want of honor or virtue, so } \\
\text { much as downright ignorance of the nature of coin, credit, and circulation. }\end{array}$ \\
\hline $\begin{array}{l}\text { Noctor M, Stoney } \\
\text { S, Stradling R } \\
(1992)\end{array}$ & $\begin{array}{l}\text { Financial literacy as the decision-making ability regarding money } \\
\text { management. Defined the term, "the ability to make informed judgments } \\
\text { and to take effective decisions regarding the use and management of money }\end{array}$ \\
\hline $\begin{array}{l}\text { Moore DL } \\
\text { (2003) }\end{array}$ & $\begin{array}{l}\text { Financial knowledge, experiences, and behaviors are linked in a relational } \\
\text { way. Financial experiences and behaviors together contribute to financial } \\
\text { knowledge levels and gains in competency. Key to this assumption is the } \\
\text { idea that with more experience and education, individuals become more } \\
\text { sophisticated and competent in their financial dealings. }\end{array}$ \\
\hline $\begin{array}{l}\text { OCDE } \\
(2005)\end{array}$ & $\begin{array}{l}\text { The process by which financial consumers/investors improve their } \\
\text { understanding of financial products and concepts and, through information, } \\
\text { instruction and/or objective advice, develop the skills and confidence to } \\
\text { become more aware of financial risks and opportunities, to make informed } \\
\text { choices, to know where to go for help, and to take other effective actions to } \\
\text { improve their financial well-being. }\end{array}$ \\
\hline $\begin{array}{l}\text { Widdowson D, } \\
\text { Hailwood K } \\
\quad(2007)\end{array}$ & $\begin{array}{l}\text { Financial literacy includes basic computation ability, understanding the } \\
\text { yields and risks of financial decisions, familiarity with basic financial } \\
\text { management concepts, knowing the channels for consultation and assistance, } \\
\text { and the ability to understand the content of suggestions }\end{array}$ \\
\hline
\end{tabular}




\begin{tabular}{|c|c|}
\hline $\begin{array}{l}\text { Mandell L } \\
\quad(2007)\end{array}$ & $\begin{array}{l}\text { The ability to evaluate the new and complex financial instruments and make } \\
\text { informed judgments in both choice of instruments and extent of use that } \\
\text { would be in their own best long-run interest. }\end{array}$ \\
\hline $\begin{array}{l}\text { Lusardi A, } \\
\text { Mitchell OS. } \\
\text { (2008) }\end{array}$ & $\begin{array}{l}\text { Knowledge of basic financial concepts, such as the working of interest } \\
\text { compounding, the difference between nominal and real values, and the } \\
\text { basics of risk diversification. } \\
\text { The ability to make simple decisions regarding debt contracts, in particular } \\
\text { how one applies basic knowledge about interest compounding, measured in } \\
\text { the context of everyday financial choices. }\end{array}$ \\
\hline $\begin{array}{l}\text { Hung A, Parker } \\
\text { AM, Yoong J } \\
\quad(2009)\end{array}$ & $\begin{array}{l}\text { Knowledge of basic economic and financial concepts, and the ability to use } \\
\text { that knowledge and other financial skills to manage financial resources } \\
\text { effectively for a lifetime of financial wellbeing }\end{array}$ \\
\hline $\begin{array}{l}\text { Mandell L } \\
(2009)\end{array}$ & $\begin{array}{l}\text { Financial literacy generally refers to the ability of consumers to make } \\
\text { financial decisions in their own best short- and long-term interests. }\end{array}$ \\
\hline $\begin{array}{l}\text { Huston SJ } \\
\quad(2010)\end{array}$ & $\begin{array}{l}\text { Financial literacy education, which is aimed at improving a person's level of } \\
\text { knowledge and/or ability, can and should be tailored to suit different } \\
\text { demographics, life stages and learning styles-certainly not as a } \\
\text { one-size-fits-all approach. Thus, it is important to clearly differentiate } \\
\text { financial literacy from financial literacy education. } \\
\text { Financial literacy has an additional application dimension which implies that } \\
\text { an individual must have the ability and confidence to use his/her financial } \\
\text { knowledge to make financial decisions. }\end{array}$ \\
\hline $\begin{array}{l}\text { Remund DL } \\
\quad(2010)\end{array}$ & $\begin{array}{l}\text { Financial literacy is a measure of the degree to which one understands key } \\
\text { financial concepts and possesses the ability and confidence to manage } \\
\text { personal finances through appropriate, short-term decision making and } \\
\text { sound, long-range financial planning, while mindful of life events and } \\
\text { changing economic conditions }\end{array}$ \\
\hline $\begin{array}{l}\text { Lusardi A, } \\
\text { Mitchell OS } \\
\qquad(2011)\end{array}$ & $\begin{array}{l}\text { The knowledge of basic financial concepts and ability to do } \\
\text { simple calculations. }\end{array}$ \\
\hline $\begin{array}{l}\text { Atkinson A, } \\
\text { Messy F } \\
\text { (2012) }\end{array}$ & $\begin{array}{l}\text { Financial literacy is a combination of knowledge, attitude and behavior. } \\
\text { Financial literacy is a combination of awareness, knowledge, skill, attitude } \\
\text { and behavior necessary to make sound financial decisions and ultimately } \\
\text { achieve individual financial wellbeing }\end{array}$ \\
\hline OECD, 2014 & $\begin{array}{l}\text { Knowledge and understanding of financial concepts and risks, and the skills, } \\
\text { motivation and confidence to apply such knowledge and understanding in } \\
\text { order to make effective decisions across a range of financial contexts, to } \\
\text { improve the financial well-being of individuals and society, and to enable } \\
\text { participation in economic life. }\end{array}$ \\
\hline $\begin{array}{l}\text { Xiao JJ, Chen C, } \\
\text { Sun L } \\
(2015)\end{array}$ & $\begin{array}{l}\text { Financial literacy can be categorized as objective or subjective. Objective } \\
\text { financial literacy refers to consumers' actual financial knowledge, usually } \\
\text { measured by scores of financial quizzes. Subjective financial literacy is the } \\
\text { financial knowledge level self-evaluated by consumers themselves. Both } \\
\text { objective and subjective financial literacy factors were used to predict } \\
\text { financial behavior }\end{array}$ \\
\hline $\begin{array}{l}\text { Paiella M } \\
\quad(2016)\end{array}$ & $\begin{array}{l}\text { Financial literacy is the ability to collect important information, and also } \\
\text { differentiate between diverse financial options, discussing financial issues, } \\
\text { planning and proficiently answer that affect financial decision making. }\end{array}$ \\
\hline $\begin{array}{l}\text { Firli A } \\
(2017)\end{array}$ & $\begin{array}{l}\text { Financial literacy is a conceptual model containing six basic components: (1) } \\
\text { Saving Borrowings; (2) Personal Budgeting; (3) Economic Issues; (4) } \\
\text { Financial Concepts; (5) Financial Services; (6) Investing. }\end{array}$ \\
\hline
\end{tabular}




\begin{tabular}{cl}
$\begin{array}{c}\text { Kasman M, } \\
\text { Heuberger B, } \\
\begin{array}{c}\text { Hammond RA } \\
(2018)\end{array}\end{array}$ & $\begin{array}{c}\text { Financial literacy as a construct that reflects dynamic relationships between } \\
\text { knowledge, skills, behavior, and other relevant factors }\end{array}$ \\
\hline $\begin{array}{c}\text { Hanson TA, } \\
\text { Olson PM } \\
(2018)\end{array}$ & $\begin{array}{l}\text { Financial literacy has been shown to affect a wide range of financial behavior; } \\
\text { therefore, understanding methods to improve financial literacy is vital for } \\
\text { improving financial outcomes in personal finance. }\end{array}$ \\
\hline $\begin{array}{c}\text { Kadoya Y, } \\
\text { Khan MSR } \\
(2020)\end{array}$ & $\begin{array}{c}\text { Financial literacy means understanding the value of money and how to } \\
\text { maximize the benefits of money utilization. }\end{array}$ \\
\hline & $\begin{array}{c}\text { Combination of awareness, knowledge, skills, attitudes and behaviors } \\
\text { necessary to make good financial decisions and, ultimately, achieve } \\
\text { individual financial well-being. }\end{array}$ \\
\hline
\end{tabular}

\section{References}

1. Krechovská, M. Financial Literacy as a Path to Sustainability; 2015. Available online: http://www.fek.zcu.cz/tvp/doc/2015-2.pdf (accessed on 13 August 2021).

2. Kadoya, Y.; Khan, M.S.R. Financial Literacy in Japan: New Evidence Using Financial Knowledge, Behavior, and Attitude. Sustainability 2020, 12, 3683. [CrossRef]

3. Hira, T.K. Promoting sustainable financial behaviour: Implications for education and research. Int. J. Consum. Stud. 2012, 36, 502-507. [CrossRef]

4. Zait, A.; Bertea, P.E. Financial literacy-Conceptual definition and proposed approach for a measurement instrument. J. Account. Manag. 2015, 4, 37-42.

5. Allgood, S.; Walstad, W. Financial literacy and credit card behaviors: A cross-sectional analysis by age. Numeracy 2013, 6, 1-26. [CrossRef]

6. Knoll, M.A.Z.; Houts, C. The Financial Knowledge Scale: An Application of Item Response Theory to the Assessment of Financial Literacy. J. Consum. Aff. 2012, 46, 381-410. [CrossRef]

7. Li, X. When financial literacy meets textual analysis: A conceptual review. J. Behav. Exp. Finance 2020, 28, 100402. [CrossRef]

8. Fernandes, D.; Lynch, J.G., Jr.; Netemeyer, R.G. Financial literacy, financial education, and downstream financial behaviors. Manag. Sci. 2014, 60, 1861-1883. [CrossRef]

9. Martínez, M.L.C.; Aragón, P. Twitter, del sondeo a la sonda: Nuevos canales de opinión, nuevos métodos de análisis. Más Poder Local 2012, 12, 50-56.

10. Garay Anaya, G. Las finanzas conductuales, el alfabetismo financiero y su impacto en la toma de decisiones financieras, el bienestar económico y la felicidad. Rev. Perspect. 2015, 36, 7-34.

11. Sanfey, A.G.; Loewenstein, G.; McClure, S.M.; Cohen, J.D. Neuroeconomics: Cross-currents in research on decision-making. Trends Cogn. Sci. 2006, 10, 108-116. [CrossRef] [PubMed]

12. Zahera, S.A.; Bansal, R. Do investors exhibit behavioral biases in investment decision making? A systematic review. Qual. Res. Financ. Mark. 2018, 10, 210-251. [CrossRef]

13. Hilgert, M.A.; Hogarth, J.M.; Beverly, S.G. Household financial management: The connection between knowledge and behavior. Fed. Res. Bull. 2003, 89, 309.

14. Bakken, M.R. Money Management Understanding of Tenth Grade Students. Master's Thesis, University of Alberta, Edmonton, AB, Canada, 1966.

15. Danes, S.M.; Hira, T.K. Money Management Knowledge of College. J. Stud. Financ. Aid 1987, $17,1$.

16. Bernheim, B.D.; Garrett, D.; Maki, D. Education and saving:: The long-term effects of high school financial curriculum mandates. J. Public Econ. 2001, 80, 435-465. [CrossRef]

17. Noctor, M.; Stoney, S.; Stradling, R. Financial Literacy: A Discussion of Concepts and Competencies of Financial Literacy and Opportunities for Its Introduction into Young People's Learning (Report Prepared for the National Westminster Bank); National Foundation for Education Research: London, UK, 1992.

18. Ouachani, S.; Belhassine, O.; Kammoun, A. Measuring financial literacy: A literature review. Manag. Finance 2020, 47, $266-281$. [CrossRef]

19. Chen, H.; Volpe, R.P. An analysis of personal financial literacy among college students. Financ. Serv. Rev. 1998, 7, 107-128. [CrossRef]

20. Lusardi, A.; Mitchell, O.S. Planning and Financial Literacy: How Do Women Fare? Am. Econ. Rev. 2008, 98, 413-417. [CrossRef]

21. Huston, S.J. Measuring Financial Literacy. J. Consum. Aff. 2010, 44, 296-316. [CrossRef]

22. Huang, J.; Nam, Y.; Sherraden, M.S. Financial Knowledge and Child Development Account Policy: A Test of Financial Capability. J. Consum. Aff. 2012, 47, 1-26. [CrossRef] 
23. Hogarth, J.M.; Hilgert, M.A. Financial knowledge, experience and learning preferences: Preliminary results from a new survey on financial literacy. Consum. Interest Annu. 2002, 48, 1-7.

24. Muñoz-Murillo, M.; Álvarez-Franco, P.B.; Restrepo-Tobón, D.A. The role of cognitive abilities on financial literacy: New experimental evidence. J. Behav. Exp. Econ. 2020, 84, 101482. [CrossRef]

25. Mason, C.; Wilson, R. Conceptualising financial literacy. Occas. Pap. 2000, 1-42. Available online: http://citeseerx.ist.psu.edu/ viewdoc/download?doi=10.1.1.1028.5352\&rep=rep1\&type=pdf (accessed on 4 July 2021).

26. Kahneman, D.; Smith, V. Foundations of behavioral and experimental economics. Nobel Prize. Econ. Doc. 2002, 1, 1-25.

27. Moore, D.L. Survey of Financial Literacy in Washington State: Knowledge, Behavior, Attitudes, and Experiences; Washington State Department of Financial Institutions: Olympia, WA, USA, 2003. [CrossRef]

28. Brüggen, E.C.; Hogreve, J.; Holmlund, M.; Kabadayi, S.; Löfgren, M. Financial well-being: A conceptualization and research agenda. J. Bus. Res. 2017, 79, 228-237. [CrossRef]

29. Worthington, A.C. Predicting Financial Literacy in Australia. Wollongon, Australia, 2006. Available online: https://ro.uow.edu. au/cgi/viewcontent.cgi? article=1124\&context=commpapers (accessed on 13 August 2021).

30. Widdowson, D.; Hailwood, K. Financial literacy and its role in promoting a sound financial system. Reserve Bank N. Z. Bull. 2007, 70,37 .

31. Lusardi, A.; Mitchell, O.S. Financial literacy around the world: An overview. J. Pension-Econ. Finance 2011, 10, 497-508. [CrossRef]

32. Huhmann, B.A.; McQuitty, S. A model of consumer financial numeracy. Int. J. Bank Mark. 2009, 27, 270-293. [CrossRef]

33. Paiella, M. Financial literacy and subjective expectations questions: A validation exercise. Res. Econ. 2016, 70, 360-374. [CrossRef]

34. Krische, S.D. Individual Investors' Financial Literacy and Numerical Skills. Contemp. Account. Res. 2014. [CrossRef]

35. Mandell, L. Financial Education in High School; University of Chicago Press: Chicago, IL, USA, 2013; pp. $257-279$.

36. Norvilitis, J.; Szablicki, P.B.; Wilson, S.D. Factors Influencing Levels of Credit-Card Debt in College Students1. J. Appl. Soc. Psychol. 2003, 33, 935-947. [CrossRef]

37. Žižek, S. A permanent economic emergency. New Left Rev. 2010, 64, 85-95.

38. Altman, E.I.; Sabato, G.; Wilson, N. The value of non-financial information in SME risk management. J. Crédit. Risk 2010, 6, 95-127. [CrossRef]

39. Altman, M. Implications of behavioural economics for financial literacy and public policy. J. Socio-Econ. 2012, 41, 677-690. [CrossRef]

40. Hung, A.A.; Parker, A.M.; Yoong, J. Defining and Measuring Financial Literacy. 2009. Available online: https://www.rand.org/ pubs/working_papers/WR708.html (accessed on 13 August 2021).

41. Remund, D.L. Financial Literacy Explicated: The Case for a Clearer Definition in an Increasingly Complex Economy. J. Consum. Aff. 2010, 44, 276-295. [CrossRef]

42. Atkinson, A.; Messy, F. Measuring financial literacy: Results of the OECD/International Network on Financial Education (INFE) pilot study. Meas. Financ. Lit. 2012. [CrossRef]

43. De Beckker, K.; De Witte, K.; Van Campenhout, G. Financial Literacy-A Cross Country Analysis. 2017. Available online: https:/ / onlinelibrary.wiley.com/doi/10.1111/ijcs.12534. (accessed on 13 August 2021).

44. Compen, B.; De Witte, K.; Schelfhout, W. The role of teacher professional development in financial literacy education: A systematic literature review. Educ. Res. Rev. 2019, 26, 16-31. [CrossRef]

45. Allgood, S.; Walstad, W. The effects of perceived and actual financial knowledge on credit card behavior. Netw. Financ. Inst. Work. Pap. 2011, 15, 1-26. [CrossRef]

46. Xiao, J.J.; Chen, C.; Sun, L. Age differences in consumer financial capability. Int. J. Consum. Stud. 2015, 39, 387-395. [CrossRef]

47. Thaler, R.H.; Sunstein, C.R.; Balz, J.P. Choice architecture. Behav. Found. Public Policy 2013. Available online: https://www. degruyter.com/document/doi/10.1515/9781400845347-029/html (accessed on 13 August 2021).

48. Thomson, S. Financing the Future: Australian Students' Results in the PISA 2012 Financial Literacy Assessment. 2014. Available online: https:/ / research.acer.edu.au/ozpisa/16/ (accessed on 13 August 2021).

49. Firli, A. Factors that Influence Financial Literacy: A Conceptual Framework. IOP Conf. Ser. Mater. Sci. Eng. 2017, 180, 12254. [CrossRef]

50. Kasman, M.; Heuberger, B.; Hammond, R.A. A Review of Large Scale Youth Financial Literacy Education Policies and Programs; The Brookings Institution, 2018. Available online: https://www.brookings.edu/wp-content/uploads/2018/10/ES_20181001 _Financial-Literacy-Review.pdf (accessed on 13 August 2021).

51. Rai, K.; Dua, S.; Yadav, M. Association of Financial Attitude, Financial Behaviour and Financial Knowledge Towards Financial Literacy: A Structural Equation Modeling Approach. FIIB Bus. Rev. 2019, 8, 51-60. [CrossRef]

52. Hanson, T.A.; Olson, P.M. Financial literacy, and family communication patterns. J. Behav. Exp. Financ. 2018, 19, 64-71. [CrossRef]

53. Behrman, J.R.; Mitchell, O.S.; Soo, C.K.; Bravo, D. How financial literacy affects household wealth accumulation. Am. Econ. Rev. 2012, 102, 300-304. [CrossRef] [PubMed]

54. Lusardi, A.; Samek, A.; Kapteyn, A.; Glinert, L.; Hung, A.; Heinberg, A. Visual tools and narratives: New ways to improve financial literacy. J. Pension-Econ. Finance 2017, 16, 297-323. Available online: https://www.cambridge.org/core/journals/ journal-of-pension-economics-and-finance/article/abs/visual-tools-and-narratives-new-ways-to-improve-financial-literacy / 6CA7426CF88099809C1460076C8357CD (accessed on 13 August 2021). [CrossRef] 
55. Sivaramakrishnan, S.; Srivastava, M.; Rastogi, A. Attitudinal factors, financial literacy, and stock market participation. Int. J. Bank Mark. 2017, 35, 818-841. [CrossRef]

56. Deuflhard, F.; Georgarakos, D.; Inderst, R. Financial Literacy and Savings Account Returns. J. Eur. Econ. Assoc. 2018, 17, 131-164. [CrossRef]

57. Duca, J.V.; Kumar, A. Financial literacy and mortgage equity withdrawals. J. Urban Econ. 2014, 80, 62-75. [CrossRef]

58. Serido, J.; Shim, S.; Tang, C. A developmental model of financial capability: A framework for promoting a successful transition to adulthood. Int. J. Behav. Dev. 2013, 37, 287-297. [CrossRef]

59. Demirguc-Kunt, A.; Klapper, L.; Singer, D. Financial Inclusion, and Inclusive Growth: A Review of Recent Empirical Evidence. 2017. Available online: https:/ / papers.ssrn.com/sol3/papers.cfm?abstract_id=2958542 (accessed on 13 August 2021).

60. Ingale, K.K.; Paluri, R.A. Financial literacy and financial behaviour: A bibliometric analysis. Rev. Behav. Financ. 2020, ahead-of-print. [CrossRef]

61. Goyal, K.; Kumar, S. Financial literacy: A systematic review and bibliometric analysis. Int. J. Consum. Stud. 2021, 45, 80-105. [CrossRef]

62. Lim, W.M. A blueprint for sustainability marketing: Defining its conceptual boundaries for progress. Mark. Theory 2016, 16, 232-249. [CrossRef]

63. Lim, W.M. Inside the sustainable consumption theoretical toolbox: Critical concepts for sustainability, consumption, and marketing. J. Bus. Res. 2017, 78, 69-80. [CrossRef]

64. Williams, S.A.; Terras, M.; Warwick, C. What do people study when they study Twitter? Classifying Twitter related academic papers. J. Doc. 2013, 69, 384-410. [CrossRef]

65. Bakshy, E.; Hofman, J.M.; Mason, W.A.; Watts, D.J. Everyone's an influencer: Quantifying influence on twitter. In Proceedings of the Fourth ACM International Conference on Web Search and Data Mining-WSDM '11, Hong Kong, China, 9-12 February 2011; pp. 65-74.

66. Luke, D. A User's Guide to Network Analysis in R; Springer Science and Business Media LLC: Berlin/Heidelberg, Germany, 2015.

67. Mariani, J.; Francopoulo, G.; Paroubek, P.; Vernier, F. The NLP4NLP Corpus (II): 50 Years of Research in Speech and Language Processing. Front. Res. Metrics Anal. 2019, 3, 37. [CrossRef]

68. Kaptein, R. Learning to Analyze Relevancy and Polarity of Tweets. CEUR Workshop Proceedings-CLEF (Online Working Notes/Labs/Workshop). 2012. Available online: http:/ / ceur-ws.org/Vol-1178/CLEF2012wn-RepLab-Kaptein2012.pdf (accessed on 13 August 2021).

69. Ahuja, V.; Shakeel, M. Twitter Presence of Jet Airways-Deriving Customer Insights Using Netmography and Wordclouds. Procedia Comput. Sci. 2017, 122, 17-24. [CrossRef]

70. Haddaway, N.R. The use of web-scraping software in searching for grey literature. Grey J. 2015, 11, 186-190.

71. Bhuta, S.; Doshi, A.; Doshi, U.; Narvekar, M. A review of techniques for sentiment analysis Of Twitter data. In Proceedings of the 2014 International Conference on Issues and Challenges in Intelligent Computing Techniques (ICICT), Ghaziabad, India, 7-8 February 2014; pp. 583-591.

72. Taboada, M.; Brooke, J.; Tofiloski, M.; Voll, K.; Stede, M. Lexicon-based methods for sentiment analysis. Comput. Linguist. 2011, 37, 267-307. [CrossRef]

73. Mohammad, S.M.; Turney, P.D. NRC Emotion Lexicon; Institute for Ocean Technology: Nova Scotia, ON, Canada, 2013.

74. Mohammad, S.M. Practical and ethical considerations in the effective use of emotion and sentiment lexicons. arXiv 2020, arXiv:2011.03492.

75. Ali, R.S.H.; El Gayar, N. Sentiment Analysis using Unlabeled Email data. In Proceedings of the 2019 International Conference on Computational Intelligence and Knowledge Economy (ICCIKE), Amity University Dubai, Dubai, United Arab Emirates, 11-12 December 2019; pp. 328-333. [CrossRef]

76. Coletta, L.F.; da Silva, N.F.; Hruschka, E.R.; Hruschka, E.R. Combining classification and clustering for tweet sentiment analysis. In Proceedings of the 2014 Brazilian Conference on Intelligent Systems, Sao Paulo, Brazil, 18-22 October 2014; pp. $210-215$.

77. Gupta, S.; Banerjee, B. Unsupervised Event Detection Using Self-learning-based Max-margin Clustering: Analysis on Streaming Tweets. IETE J. Res. 2018, 66, 569-578. [CrossRef]

78. Rehioui, H.; Idrissi, A. New Clustering Algorithms for Twitter Sentiment Analysis. IEEE Syst. J. 2020, 14, 530-537. [CrossRef]

79. Burscher, B.; Vliegenthart, R.; de Vreese, C.H. Frames beyond words: Applying cluster and sentiment analysis to news coverage of the nuclear power issue. Soc. Sci. Comput. Rev. 2016, 34, 530-545. [CrossRef]

80. Harakawa, R.; Takimura, S.; Ogawa, T.; Haseyama, M.; Iwahashi, M. Consensus Clustering of Tweet Networks via Semantic and Sentiment Similarity Estimation. IEEE Access 2019, 7, 116207-116217. [CrossRef]

81. Garre, M.; Cuadrado, J.J.; Sicilia, M.A.; Rodríguez, D.; Rejas, R. Comparación de diferentes algoritmos de clustering en la estimación de coste en el desarrollo de software. REICIS. Rev. Española Innov. Calid. Ing. Softw. 2007, 3, 6-22.

82. Fisher, D.H. Knowledge acquisition via incremental conceptual clustering. Mach. Learn. 1987, 2, 139-172. [CrossRef]

83. Hair, J.F.; Anderson, R.E.; Tatham, R.L.; Black, W.C. Análisis Multivariante; Prentice Hall Madrid: Madrid, Spain, 1999.

84. Searle, S.R.; Casella, G.; McCulloch, C.E. Variance Components; Wiley Series in Probability and Statistics: Hoboken, NJ, USA, 1992.

85. Subactagin-Matto, A.; Goncalves-Rorke, M. Improving the Fiscal Fitness of Young Adults: Translating Knowledge into Action. JANZSSA 2010, 35, 45-54. 
86. Lusardi, A.; Mitchell, O.S. Financial Literacy and Planning: Implications for Retirement Wellbeing. 2006. Available online: https: / / www.researchgate.net/publication/4878786_Financial_Literacy_and_Planning_Implications_for_Retirement_Wellbeing (accessed on 13 August 2021).

87. Campbell, J.Y. Household Finance. J. Financ. 2006, 61, 1553-1604. [CrossRef]

88. Ameliawati, M.; Setiyani, R. The Influence of Financial Attitude, Financial Socialization, and Financial Experience to Financial Management Behavior with Financial Literacy as the Mediation Variable. KnE Soc. Sci. 2018, 3, 811-832. [CrossRef]

89. Anderson, J.; Richard, H.; Thaler, C.R. Nudge: Improving Decisions about Health, Wealth, and Happiness. Econ. Philos. 2010, 26, 369. [CrossRef]

90. Gómez, F. Educación Financiera: Retos y Lecciones a Partir de Experiencias Representativas en el Mundo. 2009. Available online: http:/ / repositorioproyectocapital.com/wp-content/uploads/2018/02/En-breve-10-educacion-financiera-retos-lecciones2009-spa.pdf (accessed on 13 August 2021).

91. Taylor, M.A.; Geldhauser, H.A. Low-income older workers. In Aging and Work in the 21st Century; Lawrence Erlbaum Associates Publishers: Hillsdale, NJ, USA, 2007; pp. 25-50.

92. Ispierto, A.; Martínez-García, I.; Ruiz Suárez, G.R. Educación Financiera y Decisiones de Ahorro e Inversión. un Análisis de la Encuesta de Competencias Financieras (ECF) (Financial Education and Savings and Investment Decisions: An Analysis of the Survey of Financial Competences (ECF)). 2021. Available online: https://www.cnmv.es/DocPortal/Publicaciones/ MONOGRAFIAS/Encuesta_de_comp_financ_ES.pdf (accessed on 13 August 2021).

93. Taft, M.K.; Hosein, Z.Z.; Mehrizi, S.M.T. The Relation between Financial Literacy, Financial Wellbeing and Financial Concerns. Int. J. Bus. Manag. 2013, 8, p63. [CrossRef]

94. Goetzmann, W.N. Money Changes Everything; Princeton University Press: Princeton, NJ, USA, 2017.

95. Zapata-Aguilar, A.; Cabrera-Ignacio, E.; Hernández-Arce, J.; Martínez-Morales, J. Educación financiera entre jóvenes universitarios: Una visión general. Educación 2016, 3, 1-8.

96. Lusardi, A. Financial literacy: Do people know the ABCs of finance? Public Underst. Sci. 2015, 24, 260-271. [CrossRef] [PubMed]

97. Grohmann, A.; Menkhoff, L. School, parents, and financial literacy shape future financial behavior. DIW Econ. Bull. 2015, 5, 407-412.

98. Zaleskiewicz, T.; Traczyk, J. Emotions and Financial Decision Making, Psychological Perspectives on Financial Decision Making; Springer: Berlin/Heidelberg, Germany, 2020; pp. 107-133. 